\title{
Dziewięcioletnie przeżycie ogólne w miejscowo zaawansowanej, następnie uogólnionej postaci niedrobnokomórkowego raka płuca. Opis przypadku
}

\author{
Ewelina Bigos ${ }^{1}$, Jolanta Łuniewska-Bury' ${ }^{1}$ Cezary Chudobiński ${ }^{2}$, Jacek Fijuth ${ }^{1}$
}

\begin{abstract}
Rak płuca jest najczęściej występującym nowotworem na świecie. W Polsce znajduje się na pierwszej pozycji wśród zachorowalności na nowotwory u mężczyzn, na drugiej u kobiet. Jest on najczęstszą przyczyną zgonów z powodu nowotworów złośliwych. Według prognoz do 2025 roku w populacji polskiej, w grupie chorych po 70. roku życia należy spodziewać się wzrostu zachorowalności i liczby zgonów. Leczenie chorych na płaskonabłonkowego raka płuca zależy od stopnia zaawansowania klinicznego. Średnie przeżycia chorych zależą od stopnia zaawansowania, w III stopniu zaawansowania klinicznego wynoszą według większości autorów około 17 miesięcy, w przypadku choroby uogólnionej jedynie 9 miesięcy. Autorzy przedstawiają opis przypadku 9-letniego przeżycia ogólnego u chorej na płaskonabłonkowego raka płuca z wyjściowym stopniem zaawansowania klinicznego IIIA, następnie z chorobą w IV stopniu zaawansowania klinicznego.
\end{abstract}

\section{Nine years survival with non-small cell lung cancer. Case report}

Lung cancer is the most frequent tumour worldwide. In Poland lung cancer has the highest incidence of any cancer in the male population. It has a poor survival prognosis and is the most frequent cause of death in the general population. The Polish forecast for year 2025 shows that the mortality rate will increase, especially in the group over 70 years old. Generally modality treatment depends on staging system. The first management step for non-small cell lung cancer is to decide whether the treatment aim is definitive or palliative and whether the tumour is resectable or unresectable. Survival rate in stage III according to many authors is some 17 months, but in the case of generalised disease is only about 9 months. The authors present a case report of 9 years survival with initial clinical stage IIIA, thereafter with disease stage IV.

Słowa kluczowe: niedrobnokomórkowy rak płuca, przeżycie ogólne, radioterapia, opis przypadku Key words: non-small cell lung cancer, overall survival, radiation therapy, case report

NOWOTWORY Journal of Oncology 2014; 64, 3: 264-269

\section{Wprowadzenie}

Rak płuca jest najczęściej występującym nowotworem na świecie (1,3 mln na 11 mln wszystkich nowo zarejestrowanych przypadków rocznie) oraz najczęstszą przyczyną zgonów (1,2 mln na 6,7 mln zgonów spowodowanych nowotworami) [1, 2].W Polsce rak płuca jest również najczęstszym występującym nowotworem u mężczyzn (ok. 15000 przy- padków rocznie według Krajowego Rejestru Nowotworów) i drugim co do częstości nowotworem u kobiet (ok. 6000 przypadków rocznie). Jest również najczęstszą przyczyną zgonów z powodu nowotworów złośliwych. W Polsce wskaźnik 5-letnich przeżyć wynosi 10\% dla mężczyzn i 15\% dla kobiet [3-5]. Prognozuje się, iż do 2025 roku w populacji polskiej, w grupie chorych starszych (po 70. roku życia) na-

${ }^{1}$ Zakład Teleradioterapii

2Zakład Diagnostyki Obrazowej

Regionalny Ośrodek Onkologiczny, Wojewódzki Specjalistyczny Szpital im. M. Kopernika w Lodzi 
dal należy spodziewać się wzrostu zachorowalności i liczby zgonów [6]. Raki niedrobnokomórkowe charakteryzują się różnorodnością utkania histologicznego, a najczęstszymi postaciami są: rak płaskonabłonkowy, gruczolakorak, rak wielkokomórkowy, rak gruczołowo-płaskonabłonkowy, rak mięsakowy oraz inne nieokreślone raki niedrobnokomórkowe.

Leczenie chorych na płaskonabłonkowego raka płuca zależy od stopnia zaawansowania klinicznego. Resekcja miąższu płuca jest leczeniem z wyboru we wczesnych postaciach, czyli w I ill stopniu oraz u wybranych chorych w stopniu zaawansowania IIIA. W przypadku braku możliwości przeprowadzenia leczenia chirurgicznego zazwyczaj wskazana jest radykalna radioterapia. Leczenie miejscowo zaawansowanej choroby uzależnione jest od cechy N.W stopniu T3N1 i T3N2 możliwe jest przeprowadzenie leczenia operacyjnego skojarzonego z chemioterapią. W pozostałych przypadkach postępowaniem z wyboru pozostaje leczenie skojarzone - radiochemioterapia. IV stopień zaawansowania jest zazwyczaj wskazaniem do leczenia paliatywnego bądź objawowego. W przypadku stwierdzenia pojedynczego ogniska przerzutowego możliwe jest agresywne leczenie z wykorzystaniem chirurgii lub radiochirurgii.

Średnie przeżycia chorych na niedrobnokomórkowego raka płuca w III stopniu zaawansowania wynoszą według większości autorów około 17 miesięcy, w przypadku choroby uogólnionej jedynie 9 miesięcy [7-9].

Autorzy przedstawiają przypadek chorej na płaskonabłonkowego raka płuca z wyjściowym stopniem zaawansowania IIIA, następnie z przerzutami do tarczycy, wątroby, trzustki i drugiego płuca, u której po wieloetapowym leczeniu uzyskano dziewięcioletnie przeżycie ogólne.

\section{Opis przypadku}

Kobieta w wieku 58 lat, paląca (20 paczkolat), z rozpoznaniem niedrobnokomórkowego płaskonabłonkowego raka płuca prawego została przyjęta do Regionalnego Ośrodka Onkologicznego w Łodzi. Stopień zaawansowania klinicznego ustalono na IIIA (T3N2). W 3. segmencie prawego płuca stwierdzono litą zmianę o średnicy $23 \times 25 \times 24$ mm, gładko zarysowaną, otoczoną zmianami zapalnymi, powiększone węzły chłonne o średnicy $35 \times 20 \mathrm{~mm}$ przedtchawiczo, $23 \times 20 \mathrm{~mm}$ przy aorcie wstępującej i $34 \times 25 \mathrm{~mm}$ w górnym biegunie wnęki prawej. Leczenie rozpoczęto w lutym 2004 roku od podania 3 kursów chemioterapii według schematu PG (cisplatyna, gemcytabina). Na podstawie tomografii komputerowej stwierdzono całkowitą regresję zmian w klatce piersiowej. Po wykluczeniu przerzutów odległych zakwalifikowano chorą do zabiegu operacyjnego - lobektomii górnej prawostronnej. W pooperacyjnym badaniu stwierdzono zmiany przerzutowe w węzłach chłonnych grupy IV po stronie prawej i grupy VII. Ze względu na uzyskany wynik histopatologiczny zakwalifikowano chorą do uzupełniającej radioterapii na obszar loży guza i regio- nalnych węzłów chłonnych śródpiersia. Chora otrzymała dawkę całkowitą $66 \mathrm{~Gy}$, podaną w 33 frakcjach. Zastosowano technikę radioterapii konformalnej (3D conformal radiotherapy - 3D-CRT). Chora pozostawała w dalszej obserwacji ambulatoryjnej. Na podstawie badania fizykalnego, badań biochemicznych i obrazowych nie stwierdzono progresji miejscowej ani rozsiewu choroby.

Po 4 latach od zakończenia radioterapii radykalnej, na podstawie kontrolnych obrazów z tomografii komputerowej, stwierdzono hypoechogeniczną zmianę ogniskową o największym wymiarze 5,5 cm w lewym płacie tarczycy. Obraz cytologiczny uzyskany drogą biopsji aspiracyjnej cienkoigłowej odpowiadał przerzutowi niedrobnokomórkowego płaskonabłonkowego raka płuca. Lewy płat tarczycy usunięto, a lożę guza wraz z pozostałym miąższem gruczołu tarczowego, z uwagi na komórki nowotworowe obecne w linii cięcia oraz zatory w naczyniach, napromieniono uzupełniająco, stosując technikę radioterapii konformalnej 3D-CRT, do dawki całkowitej 30 Gy w 10 frakcjach.

Po 3 miesiącach stwierdzono u chorej na pograniczu trzonu i ogona trzustki hypoechogeniczną zmianę ogniskową o średnicy $17 \mathrm{~mm}$. Biopsja aspiracyjna cienkoigłowa pod kontrolą ultrasonografii potwierdziła przerzutowy charakter zmiany: carcinoma non-microcellulare metastaticum necroticans. Chorą zakwalifikowano do 4 cykli chemioterapii według schematu PG (cisplatyna, gemcytabina). Następnie wykonano laparotomię, podczas której usunięto trzon, ogon trzustki i śledzionę. Po zastosowanym leczeniu pacjentka pozostawała w remisji, w dobrym stanie ogólnym przez kolejne dwa lata. Badania kontrolne nie wskazywały na rozsiew choroby.

W trakcie dalszej obserwacji ujawniono pakiet węzłów chłonnych nadobojczykowych po stronie lewej, o maksymalnej średnicy $40 \mathrm{~mm}$ (ryc. 1). Opis mikroskopowy potwierdził atypowe komórki o charakterze przerzutowym. Węzły chłonne usunięto chirurgicznie, a lożę napromieniono wiązką elektronów do dawki 18 Gy, po 2 Gy na frakcję (ryc. 2). Wysokość dawki limitowana była poprzednio przeprowadzonym leczeniem z zastosowaniem radioterapii na obszar regionalnego układu chłonnego płuca oraz tarczycy.

Na przełomie 2008 i 2009 roku w wykonanym kontrolnie badaniu tomografii komputerowej stwierdzono w prawym płacie wątroby pojedyncze ognisko przerzutowe o maksymalnej średnicy $10 \mathrm{~mm}$, potwierdzone w badaniu ultrasonograficznym i badaniu cytologicznym. Zastosowano chemioterapię ( 6 cykli w oparciu o docetaksel), uzyskując efekt całkowitej regresji, potwierdzonej w badaniach obrazowych.

W kolejnej, kontrolnej tomografii komputerowej, stwierdzono w 10. segmencie lewego płuca pojedynczą zmianę patologiczną o średnicy $9 \mathrm{~mm}$, o jednoznacznym charakterze przerzutowym (ryc. 3). Podano 45 Gy w 3 frakcjach metodą radiochirurgii pozaczaszkowej (stereotactic body radiation therapy - SBRT), wykorzystując bramkowanie oddecho- 


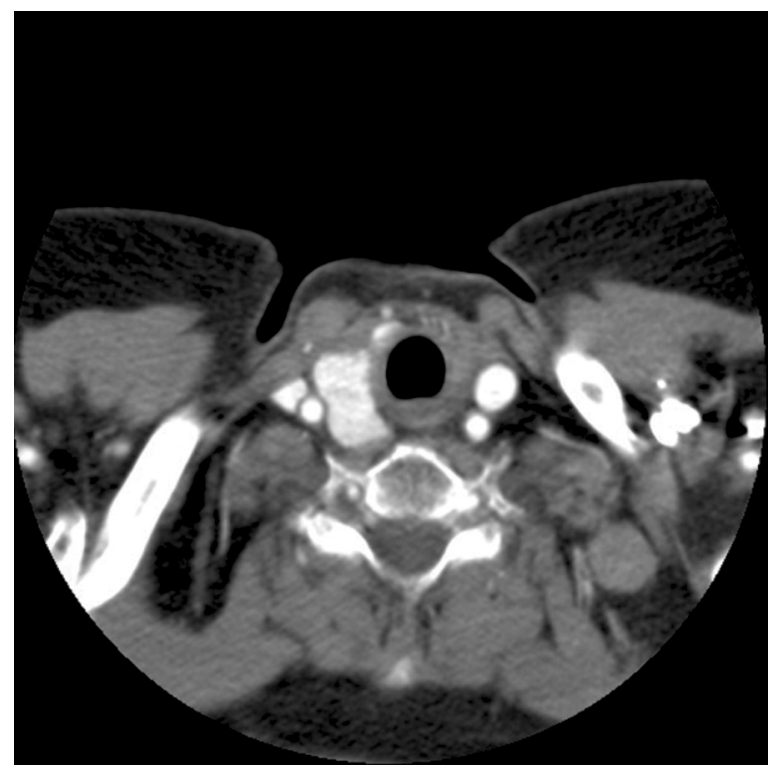

Rycina 1. Obraz z CT uwidaczniający pakiet węzłów chłonnych nadobojczykowych o średnicy $40 \mathrm{~mm}$

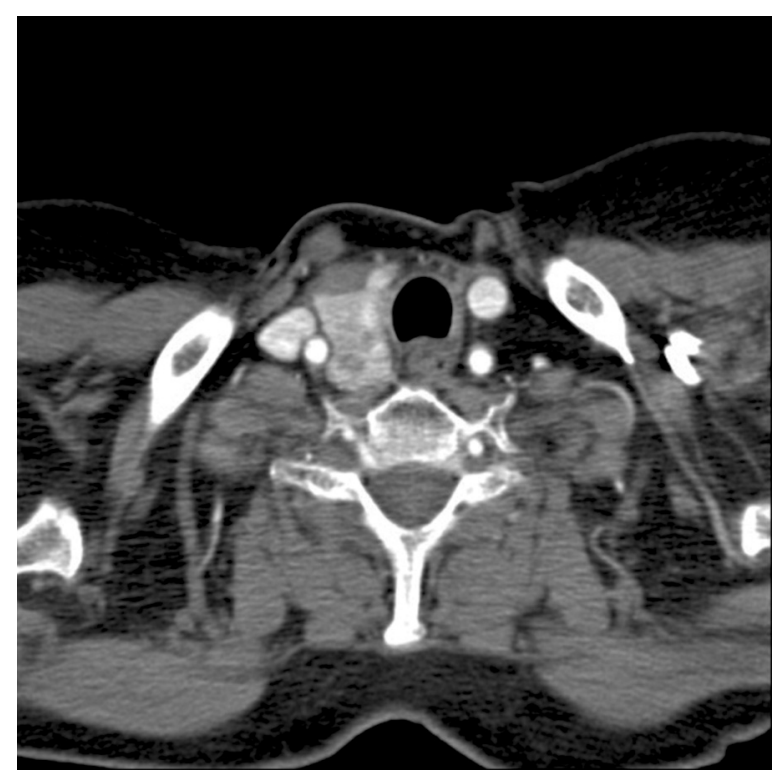

Rycina 2. Obraz kontrolny w CT po zastosowanym leczeniu

we (ryc. 4, 5). W cyklicznie wykonywanych, naprzemiennych kontrolnych badaniach tomografii komputerowej i PET-CT z użyciem FDG $(3,6,12,24,36$ miesięcy od zakończonego ostatniego leczenia z zastosowaniem radioterapii) nie stwierdzono ognisk aktywnego procesu rozrostowego (ryc. 6).

Chora z wyjściowo miejscowo zaawansowanym rakiem płuca prawego dzięki regularnie wykonywanym badaniom kontrolnym i skojarzonym wieloetapowym leczeniu osiągnęła 9-letnie przeżycie, będąc w dobrym stanie ogólnym. Pozostaje nadal pod ścisłą obserwacją Regionalnego Ośrodka Onkologicznego w Łodzi.

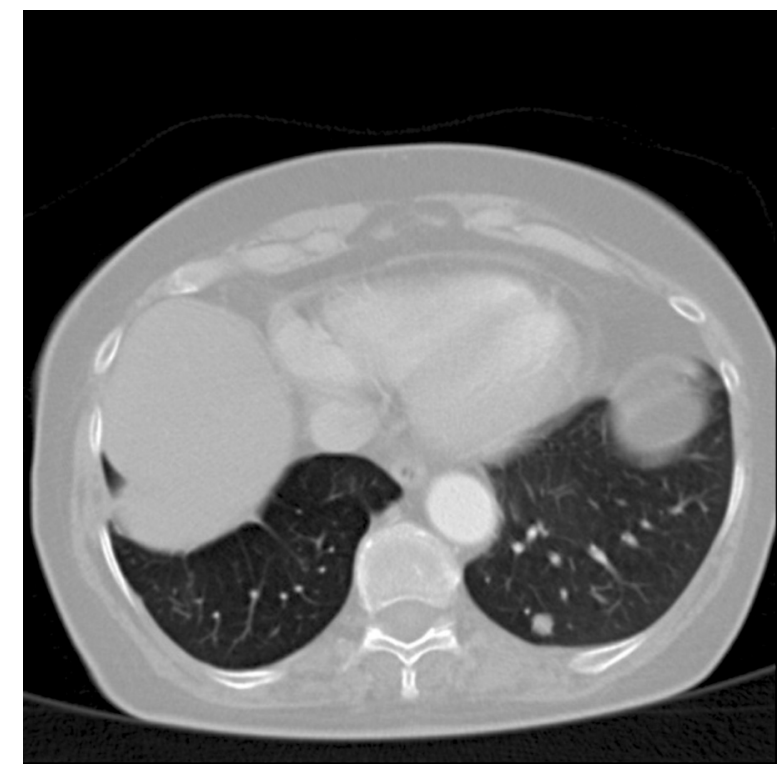

Rycina 3. Obraz z tomografii komputerowej przedstawiający ognisko przerzutowe w płucu lewym

\section{Omówienie}

Przedstawienie chorej (palącej) na płaskonabłonkowego raka płuca w postaci miejscowo zaawansowanej, a następnie uogólnionej, w tym z przerzutami do tarczycy i drugiego płuca, wydaje się uzasadnione z kilku powodów.

Rak niedrobnokomórkowy płuca jest powszechnym problemem klinicznym w Polsce ina świecie, według danych epidemiologicznych stanowi około $80 \%$ wszystkich przypadków nowotworów płuc. Około $40 \%$ z nich to przypadki zaawansowane miejscowo (IIIA i IIIB). Pięcioletnie przeżycie chorych w stopniu T3N2 według aktualnego piśmiennictwa wynosi około 20\%, a w przypadku uogólnionej choroby — poniżej 5\% [7, 8]. Szczególnie ważne wydają się więc próby indywidualizowania sposobu postępowania terapeutycznego, zwłaszcza u chorych w dobrym stanie ogólnym i w nietypowych przypadkach klinicznych [8-10].

Radioterapia jest bardzo istotną metodą leczenia chorych na niedrobnokomórkowego raka płuca i jej rola wciąż rośnie. Szacuje się, że u ponad 70\% ogółu chorych na raka płuca na pewnym etapie choroby konieczne jest zastosowanie jakiejś formy radioterapii. W III stopniu zaawansowania klinicznego radioterapia stanowi podstawową metodę leczenia.

Wyniki wyłącznej radioterapii są niezadowalające: 5-letnie przeżycie wynosi 5-10\%. W celu poprawy wyniku leczenia podejmowano wiele strategii. W stopniu IIIA ani leczenie z zastosowaniem chirurgii po indukcyjnej radiochemioterapii (INTO139), ani próba zastąpienia radioterapii leczeniem chirurgicznym po indukcyjnej chemioterapii (EORTC08941) nie przyniosły poprawy wyników. Aktualnie uważa się, że równoczesna radiochemioterapia znamiennie i istotnie klinicznie wydłuża czas przeżycia chorych, w porównaniu z wy- 


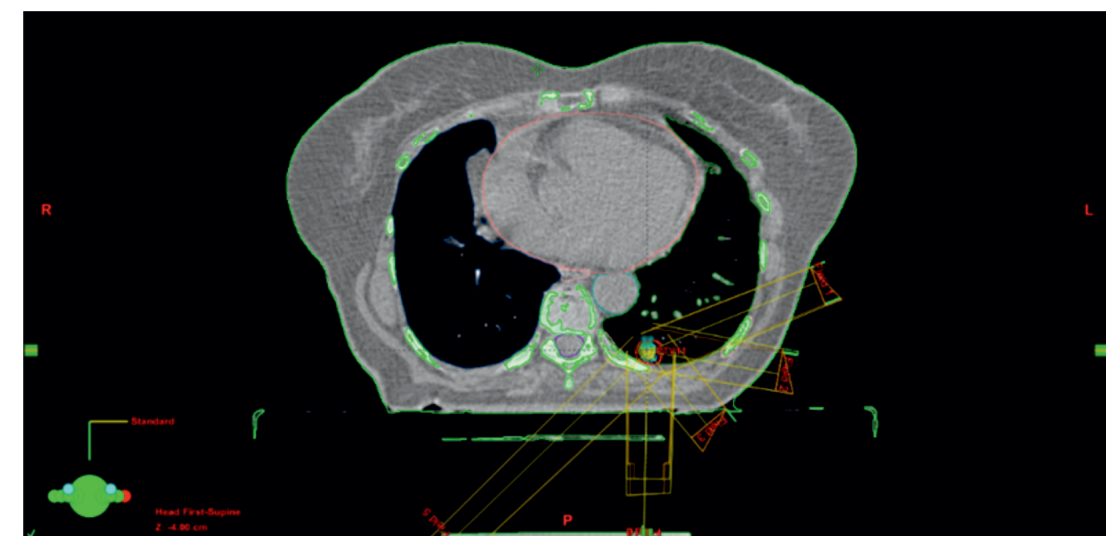

Rycina 4. Obraz z CT do planowania uwidaczniający przerzut w płucu lewym w płaszczyźnie poprzecznej

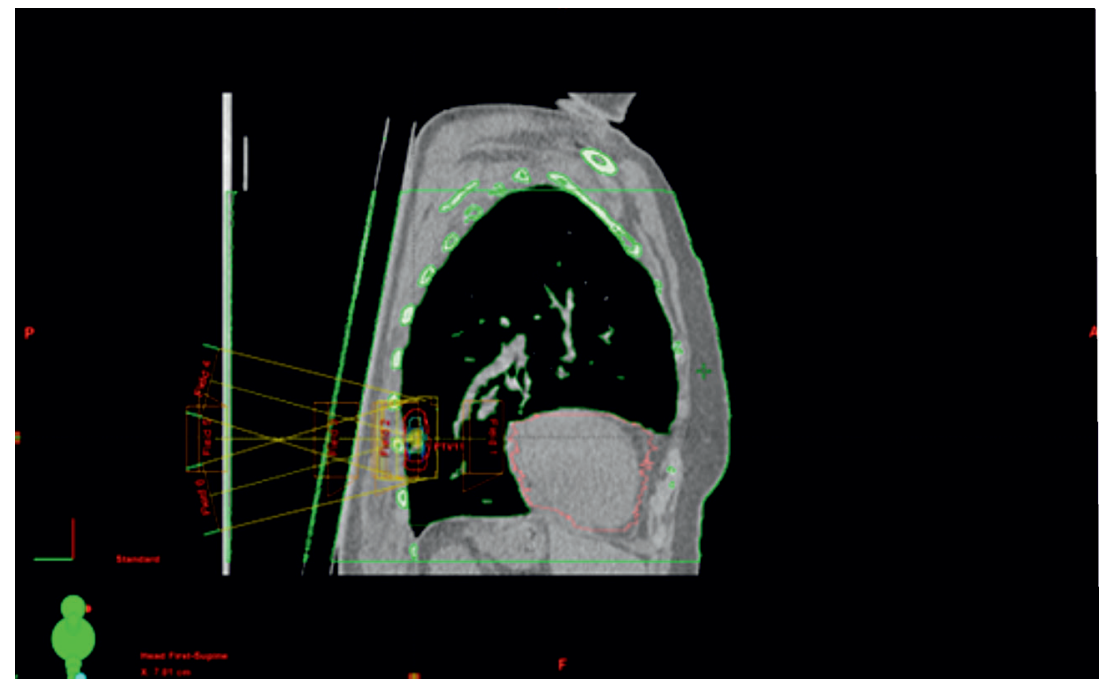

Rycina 5. Obraz z CT do planowania uwidaczniający przerzut w płucu lewym w płaszczyźnie strzałkowej

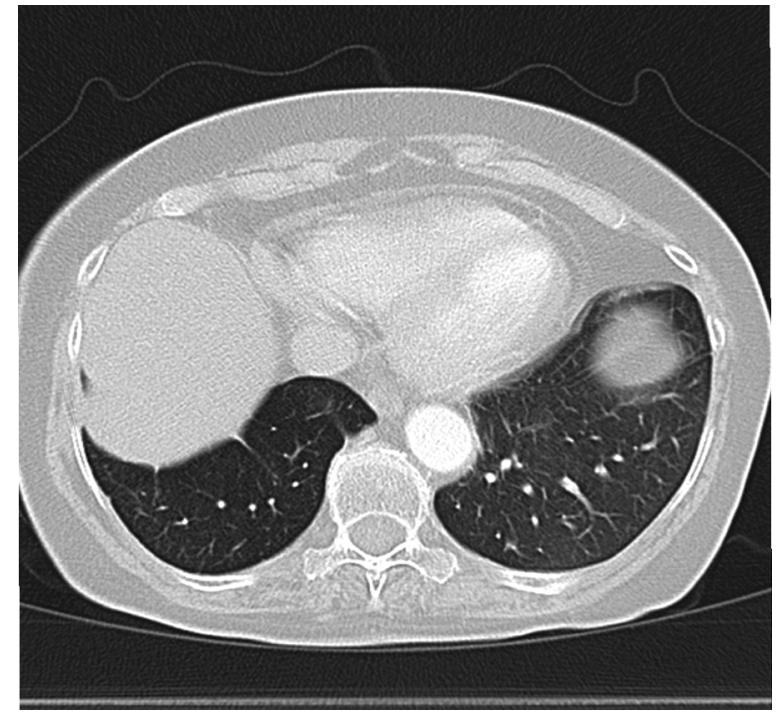

Rycina 6. Obraz z kontrolnej tomografii komputerowej — całkowita regresja zmiany przerzutowej w płucu lewym łączną radioterapią poprawiając wskaźnik 2-letnich przeżyć o 10\% [7, 8, 10-12]. Czynnikiem związanym ze skutecznością tego rodzaju postępowania jest krótszy całkowity czas leczenia, jednak należy brać pod uwagę, iż w przeprowadzanych badaniach klinicznych uczestniczyli zwykle chorzy w bardzo dobrym stanie sprawności ogólnej i z ograniczoną masą nowotworu oraz bez istotnego ubytku masy ciała. W praktyce klinicznej wielu chorych nie spełnia takich warunków, ponadto równoczesna radiochemioterapia wiąże się z około 5-krotnie wyższym ryzykiem ostrego popromiennego zapalenia przełyku. Niezadowalające wyniki leczenia, w tym wysokie ryzyko rozsiewu, były uzasadnieniem dla podjęcia prób przedoperacyjnej chemioterapii. Metaanaliza opublikowana w 2010 roku (Bozcuk H.) wykazała, że zastosowanie indukcyjnej chemioterapii zmniejsza względne ryzyko zgonu po 2 latach o 9\% w porównaniu z wyłączną radioterapią. Stanowi to przesłankę do stosowania indukcyjnej chemioterapii w oparciu o pochodne platyny, przy czym optymalna 
i jednoznaczna strategia postępowania nie została ustalona. Znaczenie chirurgii w leczeniu miejscowo zaawansowanego raka płuca jest kwestią kontrowersyjną, podnoszoną również przez panelistów National Comprehensive Cancer Network, NCCN. Wiadomo, że w przypadku obecności cechy N2 leczenie chirurgiczne nie przynosi zadowalających wyników, randomizowane badania oceniające rolę chirurgii w przypadku tej cechy nie potwierdzają bowiem zysku w postaci dłuższych przeżyć ogólnych [8, 9, 12, 13]. Eksperci NCCN dopuszczają jednak chirurgię u wyselekcjonowanych chorych z cechą N2, zwłaszcza u tych, którzy odpowiadają na indukcyjną chemioterapię. Zaletą chemioterapii indukcyjnej jest ponadto możliwość stosunkowo bezpiecznego i pewnego podania pełnych dawek cytostatyków. Populacja chorych z cechą N2 jest heterogenna i każdy przypadek kliniczny powinien być traktowany indywidualnie. Rekomendacje polskie (PUO, 2013) w przypadku stopnia zaawansowania klinicznego IIIA (T3N2) zezwalają na podanie 2-3 cykli chemioterapii przedoperacyjnej w oparciu o cisplatynę i jeden z leków trzeciej generacji (winorelbina, gemcytabina, paklitaksel, docetaksel), następnie weryfikację odpowiedzi w obrębie węzłów chłonnych oraz w przypadku uzyskania odpowiedzi - zakwalifikowanie chorego do lobektomii z usunięciem węzłów chłonnych wnęki i śródpiersia. Takie postępowanie przeprowadzone było w opisywanym przypadku. Odstępstwem od obowiązujących obecnie standardów było zastosowanie w przypadku rozsiewu ponownie schematu chemioterapii PG. Efekt terapeutyczny jednak uzyskano.

Postęp technologiczny radioterapii umożliwia doskonalenie efektów leczenia. Radioterapia konformalna (3D-CRT) pozwala na redukcję błędów geograficznych i zmniejszenie objętości napromienianych wysoką dawką zdrowych tkanek. Radioterapia z modulacją intensywności wiązki (intensity modulated radiotherapy — IMRT) umożliwia „modelowanie" rozkładu dawki stosownie do objętości tarczowej, z szybkim spadkiem poza tym obszarem, dzięki czemu skuteczniej chronione są zdrowe tkanki otaczające guz. W radioterapii stereotaktycznej (SBRT) natomiast wykorzystuje się zaawansowaną technikę, dzięki której można stosować dawki ablacyjne. Stosowane schematy SBRT pozwalają dostarczyć bardzo wysokie dawki (większe niż 10 Gy) na jedną frakcję, w 5 lub mniejszej liczbie frakcji. W trakcie planowania procesu tego rodzaju leczenia uwzględniany jest również zakres ruchomości guza, a cała procedura radioterapii stereotaktycznej jest możliwa do przeprowadzenia dzięki obrazowaniu 4DTK, czyli korelacji obrazu z czasem rzeczywistym. Coraz częściej metoda ta jest wykorzystywana w praktyce klinicznej zarówno do leczenia pierwotnej zmiany chorobowej, jak i zmian przerzutowych w różnych lokalizacjach [14]. W omawianym przypadku klinicznym zastosowano tą metodę przy przerzucie raka do drugiego płuca.
Klinicznie jawne przerzuty do gruczołu tarczowego są bardzo rzadkie, mimo iż w badaniach sekcyjnych częstość ich występowania sięga do 25\% wszystkich guzów tarczycy. Najczęściej stwierdzane są przerzuty raka nerki, piersi i płuca. W przypadku nowotworu płuca najczęstszym typem histologicznym dającym przerzuty do tarczycy — jest według danych z literatury — rak gruczołowy, rzadziej rak płaskonabłonkowy i drobnokomórkowy. Pacjenci z przerzutami nowotworowymi do tarczycy mają bardzo złe rokowanie, średni czas przeżycia wynosi — według piśmiennictwa - 10 miesięcy, a w przypadku przerzutu raka płuca - 2 miesiące [15-18]. Leczeniem $z$ wyboru jest $w$ takich przypadkach tyreidektomia, a ze względu na wysokie ryzyko wznowy miejscowej, zwłaszcza w przypadku, gdy zmiana nacieka torebkę gruczołu lub gdy margines chirurgiczny jest wąski, zaleca się pooperacyjną radioterapię loży tarczycy [19].W opisywanym przypadku podjęto takie postępowanie.

\section{Wnioski}

Zaprezentowany przypadek zwraca uwagę na fakt, że chorzy na płaskonabłonkowego raka płuca stanowią bardzo heterogenną grupę. Leczenie dostosowane do indywidualnej sytuacji klinicznej może przynieść choremu korzyść. Wykorzystanie w pełni technik leczenia, zwłaszcza radioterapii, ale również chirurgii i chemioterapii, pozwala na osiągnięcie bardzo dobrych efektów. Uzyskano dotychczas: 4 lata przeżycia w stadium miejscowo zaawansowanym, 5 lat przeżycia w stadium choroby zaawansowanej i 9 lat przeżycia ogólnego. Dane te różnią się znacząco od danych z piśmiennictwa dotyczących płaskonabłonkowego raka płuca w wyżej wspomnianych stopniach zaawansowania i tym samym szczególnie zachęcają do indywidualizowania metod postępowania diagnostyczno-terapeutycznego, zwłaszcza w przypadku dobrego ogólnego stanu chorego.

\section{Lek. Ewelina Bigos}

Zakład Teleradioterapii

Regionalny Ośrodek Onkologiczny

Wojewódzki Specjalistyczny Szpital im. M. Kopernika

ul. Paderewskiego 4, 93-509 Łódź

e-mail:ewebigos@gmail.com

Otrzymano: 14 sierpnia $2013 r$

Przyjęto do druku: 4 listopada 2013 r.

\section{Piśmiennictwo}

1. SEER Cancer Statistics Review. National Cancer Institute, Bethesda. Edition online, 2013.

2. Parkin DM, Bray F, Ferlay J i wsp. Global cancer statistics 2002. CA Cancer J Clin 2005; 55: 74-108.

3. Wojciechowska U, Didkowska J, Zatoński W. Wskaźniki przeżyć chorych na nowotwory złośliwe w Polsce zdiagnozowanych w latach 2000-2002. Warszawa: Centrum Onkologii — Instytut im. Marii Skłodowskiej-Curie, 2009.

4. Sant M, Allemani C, Santaquilani M i wsp. EUROCARE-4. Survival of patients diagnosed in 1995-1999. Results and commentary. EurJ Cancer 2009; 45: 931-991. 
5. Berrino F, De Angelis R, Sant M i wsp. Survival for eight major cancers and all cancers combined for European adults diagnosed in 1995-99: results of the EUROCARE-4 study. Lancet Oncol 2007; 8: 773-783.

6. Didkowska J, Wojciechowska U, Zatoński W. Prognozy zachorowalności i umieralności na nowotwory złośliwe w Polsce do 2025 roku. Warszawa: Centrum Onkologii — Instytut im. Marii Skłodowskiej-Curie; 2009, 35-37.

7. National Comprehensive Cancer Network. Clinical Practice Guidelines in Oncology Version 1.2013. http://www.nccn.org/professionals/physician_gls/f_guidelines.asp.

8. Perez and Brady's principles and practice of radiation oncology, online edition, 2013.

9. Khan AJ, Metha PS, Zusag TW i wsp. Long term disease-free survival resulting from combined modality management of patients presenting with oligometastatic, non small cell lung carcinoma (NSCLC). Radiother Oncol 2006; 81: 163-167.

10. Ramnath N, Dilling TJ, Harris LJ i wsp. Treatment of stage III non-small cell lung cancer: diagnosis and management of lung cancer. Wyd. 3. American College of Chest Physicians evidence-based clinical practice guidelines. Chest 2013; 143 (5 Suppl): e314S-40S.

11. McCloskey P, Balduyck B, Van Schil PE i wsp. Radical treatment of non-small cell lung cancer during the last 5 years. Eur $J$ Cancer 2013; 49: $1555-1564$
12. Farjah F, Flum DR, Varghese TK, Jr i wsp. Surgeon specialty and long term survival after pulmonary resection for lung cancer. Ann Thorac Surg 2009; 87: 995-1004.

13. Martins RG, D'Amico TA, Loo BW, Jr i wsp. The management of patients with stage IIIA non-small cell lung cancer with N2 mediastinal node involvement. J Natl Compr Canc Netw 2012; 10: 599-613.

14. Marcenaro $M$, Vagge $S$, Belgioia L. Ablative or palliative stereotactic body radiotherapy with helical tomotherapy for primary or metastatic lung tumor. Anticancer Res 2013; 33: 655-660.

15. Wood K, Vini L, Harmer C. Metastases to the thyroid gland: the Royal Marsden experience. Eur J surg Oncol 2004; 30: 583-588.

16. Nakhjavani MK, Gharib H, Goellner JR i wsp. Metastasis to the thyroid gland. A report of 43 cases. Cancer 1997; 79: 574-578.

17. Lievre A, Leboullleux S, Boige V i wsp. Thyroid metastases from colorectal cancer: the Institut Gustave Roussy experience. Eur J Cancer 2006; 42: 1756-1759.

18. Azevedo CR, Cezana L, Moraes ES, Synchronous thyroid and colon metastases from epidermoid carcinoma of the lung: case report. Sao Paulo Med J 2010; 128: 371-374.

19. De Ridder $M$, Sermeus AB, Urbain D i wsp. Metastases to the thyroid gland - a report of six cases. Eur J Intern Med 2003; 14: 377-379.

W dniach 5-7 września 2014 r. odbędzie się w Ustce

Konferencja naukowo-szkoleniowa „XI Usteckie Dni Onkologiczne”

\author{
Przewodniczący Komitetu Naukowego: \\ prof. Andrzej Szawłowski \\ prof. Janusz Jaśkiewicz \\ Przewodniczący Komitetu Organizacyjnego \\ dr Zoran Stojčev \\ Główne tematy: \\ Genetyka w służbie chirurgii onkologicznej \\ Powikłania chirurgiczne i onkologiczne leczenia nowotworów \\ Sesja dla pielęgniarek: Rak piersi — współczesne wyzwania i nadzieje \\ Miejsce obrad: \\ Hotel Royal Baltic, Ustka, ul. Wczasowa 26 \\ Informacje: \\ tel./faks 059/8460368, 512004399, 601490560, \\ e-mail: onkoustka@wp.pl,http://www.onko.ustka.pl
}

